\title{
Pengembangan Sistem Informasi Tracer Study Berbasis User Centered Design (UCD) Menggunakan Framework Laravel
}

\author{
Alvira Karisma Putri*, Magdalena Ariance Ineke Pakereng \\ Fakultas Teknologi Informasi, Teknik Informatika, Universitas Kristen Satya Wacana, Salatiga, Indonesia \\ Email: 1,*672017171@ @student.uksw.edu, ${ }^{2}$ ineke.pakereng@uksw.edu \\ Email Penulis Korespondensi: 672017171@ student.uksw.edu
}

\begin{abstract}
Abstrak-Riset ini bertajuk Pelaksanaan Framework Laravel dalam Pengembangan Sistem Tracer Study Berbasis Website. Ada pula kasus yang dinaikan dalam riset ini merupakan sistem yang digunakan sangat simpel serta masih memakai Google Form, sistem masih kurang nyaman sebab siapapun bisa mengisi form Tracer Study serta informasi Tracer Study hanya dipunyai oleh Wakil Dekan. Tujuan dari riset ini merupakan membuat sistem data Tracer Study berbasis website dengan memakai framework Laravel yang bermanfaat untuk menolong FKIP UKSW dalam mengumpulkan informasi Alumni. Tata cara yang digunakan dalam riset ini merupakan riset lapangan serta tata cara pengembangan memakai metode User Centered Design. Untuk menanggulangi permasalahan tersebut, penulis meningkatkan sistem Tracer Study di FKIP dengan memakai framework Laravel serta membuat login sebagai pengamanan sistem. Hasil dari riset ini merupakan terciptanya sistem data Tracer Study yang bisa memudahkan pengumpulan informasi serta bisa diakses oleh Pimpinan Fakultas serta Dosen.
\end{abstract}

Kata Kunci: Tracer Study; Framework Laravel; User Centered Design; MySQL; Pengujian Blackbox

\begin{abstract}
This research is entitled Implementation of the Laravel Framework in the Development of a Website-Based Tracer Study System. There are also cases that are raised in this research which is the system used is very simple and still uses Google Forms, the system is still uncomfortable because anyone can fill in the Tracer Study form and the information on the Tracer Study is only owned by the Deputy Dean. The purpose of this research is to create a website-based Tracer Study data system using the Laravel framework, which is useful for helping the SWCU FKIP in gathering Alumni information. The procedure used in this research is field research and development procedures using the User Centered Design method. To overcome this problem, the authors improve the Tracer Study system in FKIP by using a Laravel framework and creating a login as system security. The result of this research is the creation of a Tracer Study data system that can facilitate information gathering and can be accessed by Faculty Leaders and Lecturers.
\end{abstract}

Keywords: Tracer Study; Laravel Framework; User Centered Design; MySQL; Blackbox Testing

\section{PENDAHULUAN}

Perkembangan teknologi semakin berkembang seiring berjalannya waktu dan dari tahun ke tahun teknologi yang semakin pesat adalah framework. Hasil dari framework adalah sistem yang dibuat menjadi lebih cepat dikembangkan, lebih aman serta mudah untuk maintenance [1]. Tracer Study ialah salah satu program yang dicoba oleh segala perguruan tinggi di Indonesia, selaku wujud pengawasan Alumni perguruan tinggi, dalam artian tiap perguruan tinggi senantiasa mengevaluasi penerapannya. Dalam proses pemakaian Tracer Study, pengumpulan informasi kuesioner semacam tentang lulusan yang sudah memiliki pekerjaan, untuk mengenali berapa lama seseorang Alumni dapat memperoleh pekerjaan setelah lulus, serta sebagian hasil kuesioner data untuk digunakan sebagai rujukan kurikulum, kenaikan pendidikan, menyiapkan Alumni yang dibutuhkan dan siap dalam dunia kerja [2][3]. Perguruan tinggi memerlukan data informasi Alumni untuk mengetahui relevansi dan mengembangkan sikap profesional [4].

Sebagian perguruan tinggi masih mempunyai hambatan dalam mengelola informasi Alumni, untuk sistem dikala ini banyak perguruan tinggi memakai Google Form untuk form kuesioner Alumni. Google Form mempunyai kekurangan salah satunya merupakan kala Alumni mengisi kuesioner yang salah sehingga Alumni wajib mengisi ulang yang menimbulkan informasi menjadi menumpuk ataupun double. Sehingga membuat pengelola informasi kuesioner Alumni kebimbangan karna banyaknya informasi hanya untuk satu Alumni. Semacam halnya dengan FKIP UKSW yang terletak di Gedung E UKSW, Jl. Diponegoro 52-60 Salatiga. Dikala ini Tracer Study yang telah terdapat di FKIP UKSW Salatiga masih memakai Google Form serta informasi kuesioner yang telah diisi oleh Alumni hanya dipunyai oleh wakil dekan sehingga wakil dekan wajib mengirimkan informasi tersebut satu persatu kepada setiap Ketua Program Studi serta Pimpinan Fakultas. Bersumber pada kasus yang di dapat, hingga dicoba riset yang bertujuan membuat sistem informasi Tracer Study berbasis website memakai Framework Laravel yang bermanfaat untuk menolong FKIP UKSW dalam melaksanakan pendataan Alumni yang bisa diakses oleh tiap Dosen, Pimpinan Program Studi, serta Pimpinan Fakultas. Dengan terdapatnya sistem Tracer Study ini, diharapkan sistem bisa berjalan dengan maksimal serta menciptakan aplikasi yang bisa tingkatkan kinerja dalam melaksanakan Tracer Study dan melihat statistik data Alumni yang sudah berkerja sebagai guru maupun non guru serta dapat membantu data untuk akreditasi fakultas [5]-[7].

Berdasarkan permasalahan diatas maka dibuatlah program sistem informasi menggunakan framework Laravel dan PHP. Laravel adalah salah satu framework untuk menambah mutu perangkat lunak dengan meringankan pengeluaran pengembangan dan menambah produktifitas dengan sintak yang bersih serta fungsional. Laravel terdapat Command Line Interface yang berguna untuk membantu membangun sebuah aplikasi atau website dan Laravel memiliki fitur yang dinamakan Blade Template Engine yang dapat membuat tampilan terlihat 
estetik [8]. Sedangkan Bahasa pemrograman yang digunakan adalah PHP. Untuk database yang digunakan adalah MySQL, MySQL ialah suatu sistem database relasional, sehingga bisa mengelompokan data kedalam grup-grup ataupun tabel-tabel yang berkatan dengan data. Tiap tabel muat bidang-bidang yang terpisah, yang mempresentasikan tiap bit data. Namun dalam sistem database tidak relasional, seluruh data ditaruh pada satu bidang luas, yang kadang informasi di dalamnya sangat susah serta meletihkan buat diakses. Proses kilat dalam pencarian baris data pada MySQL dicoba dengan memakai indeks. MySQL sendiri ialah singkatan dari $M y$ Structured Query Language yang pula ialah aplikasi yang banyak digunakan oleh para pemrograman website disebabkan My Structured Query Language ialah aplikasi DBMS ataupun Database Management System [9]. Dimana MySQL yang digunakan adalah phpMyAdmin. phpMyAdmin merupakan perangkat lunak cocok digunakan dengan PHP karena perangkat ini dapat diakses melalui internet atau online. phpMyAdmin merupakan salah satu yang popular sebagai alat penyimpanan database sebagai alat administrasi MySQL [10]. Sistem ini terdapat fungsi login sebagai keamanan sistem karena sistem yang sebelumnya dapat diakses oleh semua orang, termasuk orang luar Alumni FKIP UKSW Salatiga. Terdapat fungsi tambah data, edit data, hapus data dan unduh data. Fungsi tersebut sangat berguna karena dapat mempermudah Alumni FKIP UKSW Salatiga untuk mengubah data Tracer Study yang akan dikirimkan. Dan untuk user dibuatkan hak akses untuk setiap user-nya, terdapat empat user yaitu Alumni, Dosen, Pimpinan Fakultas dan Admin. Hak akses disetiap user sesuai dengan status user karena informasi yang dibutuhkan berbeda disetiap status user dan data merupakan sebuah file yang rahasia dan tidak dapat digunakan dengan sembarangan oleh orang lain selain dengan orang yang bersangkutan [11].

Riset ini mengacu pada 3 (tiga) penelitian terdahulu. Penelitian yang berjudul Perancangan Aplikasi Tracer Study Alumni Jurusan Administrasi Bisnis Politeknik Negeri Banjarmasin Berbasis Web, membahas tentang perancangan sistem yang dapat memudahkan pengumpulan informasi tentang Alumni dan membuat membuat sistem yang mudah untuk diakses oleh Alumni [5]. Perbedaan riset ini dengan penelitian tersebut adalah pada user yang dapat mengakses sistem Tracer Study tidak hanya admin dan Alumni tetapi dosen dan pimpinan fakultas serta hasil program, dimana pada riset ini hasil program di dalam menu login dan register menggunakan 1 (satu) halaman untuk semua user. Penelitian yang berjudul Analisis dan Perancangan Sistem Informasi Tracer Study Berbasis Web, membahas tentang aplikasi Tracer Study yang dapat memudahkan bagi institusi dalam melakukan penelusuran terhadap Alumni dan memudahkan Alumni untuk mengakses sistem. Hasil program pada penelitian tersebut memakai metode Waterfall dan memakai framework CodeIgniter. Pada penelitian diperoleh user interface sesuai kebutuhan pengguna [4]. Perbedaan riset ini dengan penelitian tersebut adalah pada hasil program, dimana riset ini membuat form kuesioner yang berfungsi untuk memperbaiki kurikulum sebagai evaluasi standar kompetensi dalam dunia kerja. Penelitian yang berjudul Pengembangan Sistem Informasi Tracer Study Fakultas Ilmu Komputer Universitas Brawijaya Menggunakan Metode Rational Unified Process, membahas tentang aplikasi Tracer Study yang melakukan pendataan serta pengolahan data yang bertujuan untuk menelusuri Alumni sebagai penilaian akreditasi. Aplikasi pada penelitian menggunakan metode RUP. Dimana proses kontrol perubahan dapat dilakukan setiap fase yang ada [7]. Perbedaan riset ini dengan penelitian tersebut adalah pada riset ini menggunakan metode Waterfall dengan alur penelitian mengidentifikasi masalah, mengumpulkan data, merancang sistem, menguji sistem dan penulisan laporan. Dan menguji sistem menggunakan Blackbox Testing.

Diharapkan sistem informasi yang telah di buat ini dapat menjadi sistem yang mempermudah pekerjaan karyawan FKIP UKSW Salatiga yang mengurus data Tracer Study Alumni FKIP UKSW Salatiga dan juga mempermudah Alumni FKIP UKSW Salatiga dalam pengisian Tracer Study. Dan pihak FKIP UKSW Salatiga mendapatkan informasi tentang Alumni yang dibutuhkan dan dapat dipergunakan untuk kepentingan kampus seperti akreditasi ataupun keperluan yang lain.

\section{METODOLOGI PENELITIAN}

\subsection{User Centered Design}

User Centered Design (UCD) merupakan paradigma baru dalam pengembangan sistem berbasis web. User Centered Design (UCD) juga sering disebut sebagai human centered design. Human centered design adalah sebuah pendekatan pengembangan sistem interaktif yang secara khusus focus untuk membuat sebuah sistem berguna. Prinsip dalam User Centered Design (UCD) adalah fokus pada pengguna, perancangan terintegrasi, pengujian pengguna dan perancangan interaktif [12].

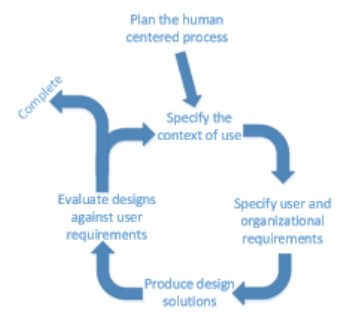

Gambar 1. Proses User Centered Design 
Gambar 1 menunjukkan proses User Centered Design, dijelaskan sebagai berikut :

1. Plan the human centered process

Menganalisis informasi ataupun teori yang berkaitan dengan proses membangun sistem yang berpusat kepada pengguna. Analisis teori, tat cara yang mempunyai tujuan untuk menggali kebutuhan yang diperlukan untuk penelitian ini serta segala kebutuhan yang terkait dengan penelitian ini [13].

2. Specify the context of use

Menjelaskan untuk apa serta dalam keadaan semacam apa pengguna hendak memakai produk.

3. Specify user and organizational requirements

Mengenali kebutuhan pengguna serta kebutuhan organisasi terhadap sistem yang hendak dibangun.

4. Product design solutions

Membangun desain sebagai solusi dari masalah yang dianalisis.

5. Evaluate design against user requirements

Melakukan evaluasi terhadap desain yang sudah dicoba pada tahap sebelumnya. Dimana desain tersebut wajib penuhi persyaratan yang diperlukan oleh pengguna. Tahap ini digunakan untuk melihat apakah tujuan pengguna dan organisasi tercapai.

\subsection{Tahapan Penelitian}

Tahapan terbagi menjadi 6 (enam), yaitu identifikasi masalah, pengumpulan data, perancangan sistem, implementasi sistem, pengujian sistem dan peulisan laporan penelitian.

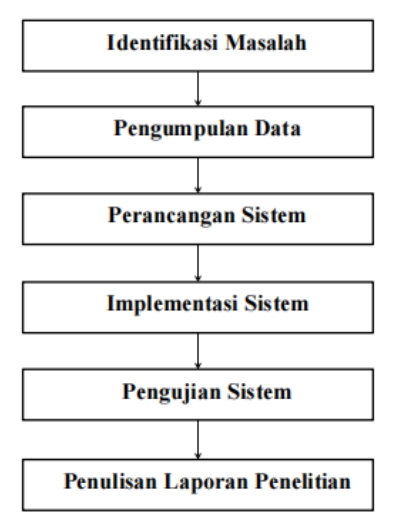

Gambar 2. Tahapan Penelitian

Gambar 2 menunjukkan tahapan penelitian, dijelaskan sebagai berikut :

1. Identifikasi Masalah

Identifikasi permasalahan terkait sistem informasi Tracer Study yang diperlukan oleh FKIP UKSW Salatiga. Pada tahap ini juga membahas tentang analisis sistem yang bertujuan untuk menguasai sistem berjalan serta mengidentifikasikan permasalahan dan mencari solusinya. Diperlukan aplikasi yang bisa membagikan data informasi Alumni mahasiswa yang terdapat di tiap jurusan ataupun program studi. Permasalahan yang ada di FKIP UKSW adalah ketika Alumni mengisi form kuesioner dengan tidak benar padahal kuesioner sudah di submit, maka dari itu Alumni harus mengisi form kuesioner dari awal dengan teliti serta data Alumni yang tidak benar dan yang baru diisi tersebut tetap masuk pada data menjadi double, itulah menjadi permasalahan karena pihak FKIP UKSW yang menangani data Tracer Study menjadi kebingungan dengan data yang diberikan dan tidak tau mana yang benar dan mana yang salah pada data Alumni yang dikirim dalam waktu yang dekat.

2. Pengumpulan Data

Mengumpulkan data terkait daftar Alumni FKIP UKSW Salatiga. Data yang dikumpulkan didapat dengan cara observasi. Data yang diperlukan antara lain data Alumni selama belajar di FKIP UKSW Salatiga dan data pertanyaan yang diperlukan untuk pengisian Tracer Study pada sistem informasi FKIP UKSW Salatiga.

3. Perancangan Sistem

Merancang sistem menggunakan framework Laravel yang sesuai dengan kebutuhan FKIP UKSW Salatiga dari data yang sudah didapat. Pada tahap ini merancang desain dan fungsi apa saja yang ingin dijalankan. Seperti membuat fungsi login untuk keamanan sistem dan memberikan hak akses kepada setiap user. Dan tidak lupa untuk merancang tampilan halaman website supaya lebih menarik dan menyenangkan ketika mengisi form kuesioner.

4. Implementasi Sistem

Membuat sistem dengan mengimplementasikan framework Laravel untuk sistem Tracer Study FKIP UKSW Salatiga. Implementasi ialah bagian dari tahapan implementasi dan pengujian unit pada tata cara Waterfall. 
Pada tahapan ini desain ke dalam bahasa pemrograman cocok kebutuhan pengguna setelah itu dicoba pengecekan terhadap materi yang sudah terbuat.

5. Pengujian Sistem

Biasanya terdapat hasil implementasi, hingga ada suatu pengujian ataupun testing [14], pengujian sistem dilakukan dengan Blackbox. Menguji sistem yang sudah dibuat dengan menjalankan proses implementasi program serta menguji hasil output dari program dengan melihat hasil yang diberikan apakah program sesuai dengan konsep yang diinginkan FKIP UKSW Salatiga. Jika sistem terdapat kekurangan maka pembuat sistem akan memperbaiki sistem dengan teliti.

6. Penulisan Laporan Penelitian

Pada tahap ini dilakukan penulisan laporan dari data yang telah didapat pada implementasi dan pengujian sistem, serta hasil sistem ini ketika dijalankan dan hasil dari laporan ini adalah sebuah artikel ilmiah.

\section{HASIL DAN PEMBAHASAN}

\subsection{Perancangan Sistem}

Perancangan sistem adalah bagaimana sistem dibangun melalui analisis sistem yang dilakukan oleh peneliti [15]. Penelitian ini menampilkan perancangan use case diagram, activity diagram, dan statechart diagram. Diagram dapat dilihat pada Gambar 3-Gambar 14.

a. Use Case Diagram

Use case diagram menggambarkan aktivitas apa saja yang ada dalam sistem. Apa saja yang terjalin didalam sistem serta siapa saja yang melaksanakan aktivitas tersebut. Use Case Diagram dapat dilihat pada Gambar 3.

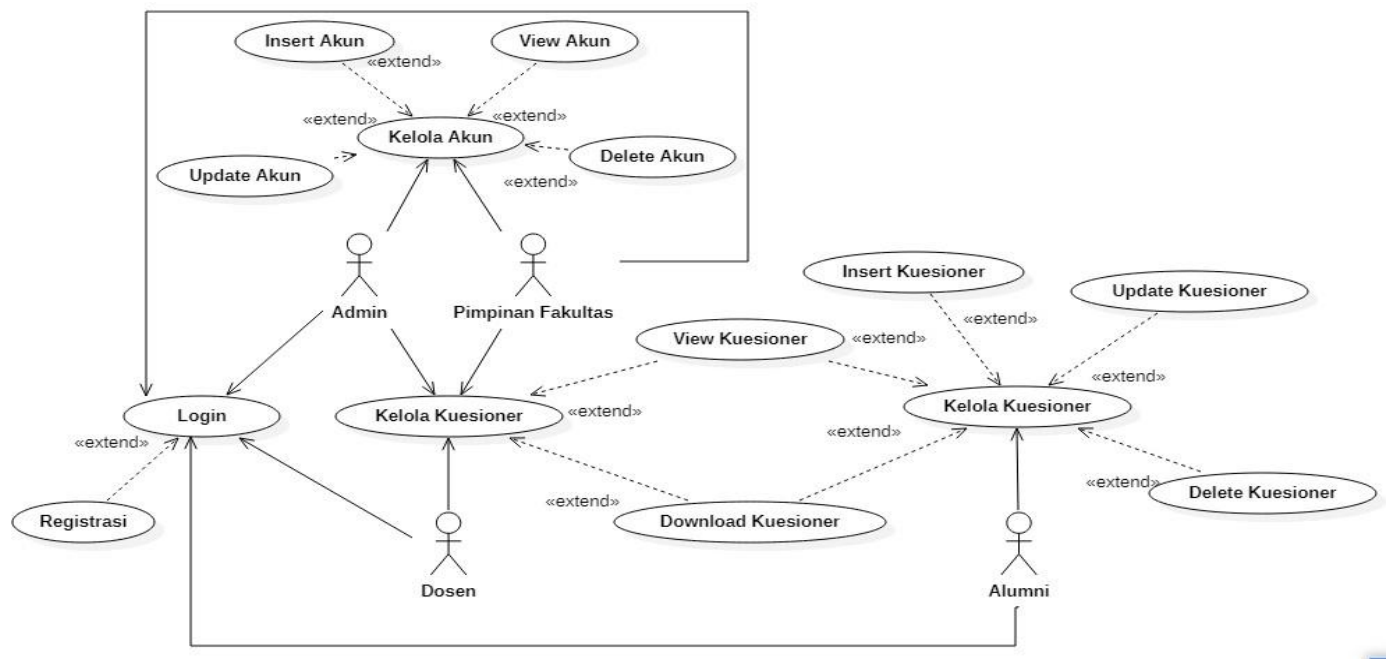

Gambar 3. Use Case Diagram

Use Case Diagram diatas terdapat aktor yang berfungsi sebagai orang yang akan mengoperasikan ataupun orang yang berhubungan dengan sistem [16]. Pada Gambar 2 terdapat 4 aktor yaitu Admin, Alumni, Dosen dan Pimpinan Fakultas, setiap aktor memiliki tugas yang berbeda-beda. Sebelum aktor melakukan tugas, aktor dijawibkan untuk registrasi dan login, kemudian aktor akan diarahkan dashboard. Setiap aktor memiliki hak akses yang berbeda, aktor Admin dan Pimpinan Fakultas memiliki akses untuk kelola akun (tambah akun, view akun, update akun dan hapus akun) dan kelola kuesioner (view kuesioner dan download kuesioner). Aktor Dosen memiliki akses untuk kelola kuesioner (view kuesioner dan download kuesioner). Dan aktor Alumni memiliki akses untuk kelola kuesioner (tambah kuesioner, view kuesioner, update kuesioner, hapus kuesioner, dan download kuesioner).

b. Activity Diagram

Activity diagram adalah diagram yang dapat memodelkan proses yang terjadi pada sebuah sistem. Activity diagram dapat dilihat pada Gambar 4-Gambar 7.

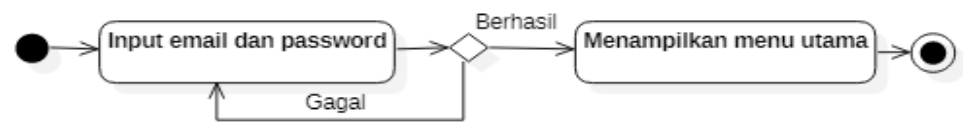

Gambar 4. Activity Diagram Login

Gambar 4 merupakan aktifitas login yang dilakukan oleh user. User melakukan login dengan cara memasukkan inputan berupa email dan password. 
ISSN 2614-5278 (media cetak), ISSN 2548-8368 (media online)

Available Online at https://ejurnal.stmik-budidarma.ac.id/index.php/mib

DOI 10.30865/mib.v5i3.3033

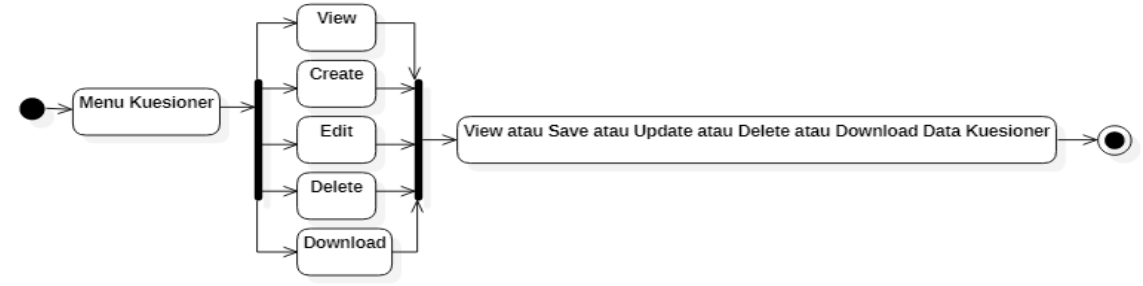

Gambar 5. Activity Diagram Kuesioner Tracer Study

Gambar 5 merupakan aktifitas pada menu Kuesioner untuk user alumni. Alumni dapat melakukan lihat detail kuesioner, tambah kuesioner, edit kuesioner, hapus kuesioner dan download kuesioner.

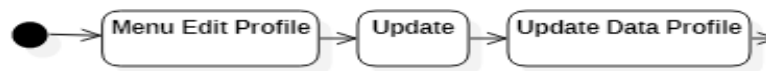

Gambar 6. Activity Diagram Profile User

Gambar 6 merupakan aktifitas pada menu Edit Profil untuk semua user. User dapat melakukan update data profil pribadi.

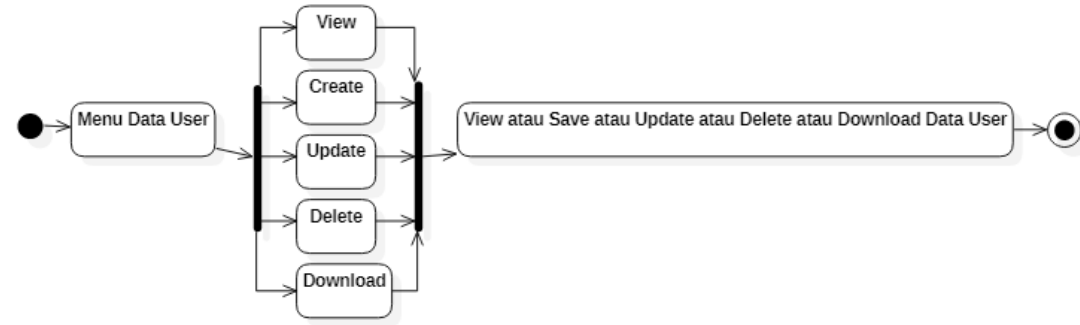

Gambar 7. Activity Diagram Data User

Gambar 7 merupakan aktifitas pada menu Data User untuk user Pimpinan Fakultas dan Admin. User dapat melakukan tambah data, lihat data, edit data, hapus data, dan download data.

c. Statechart Diagram

Statechart diagram adalah sebuah diagram yang menggambarkan, memperlihatkan serta mendeskripsikan tentang perilaku sistem. Statechart diagram dapat dilihat pada Gambar 8-Gambar 14.

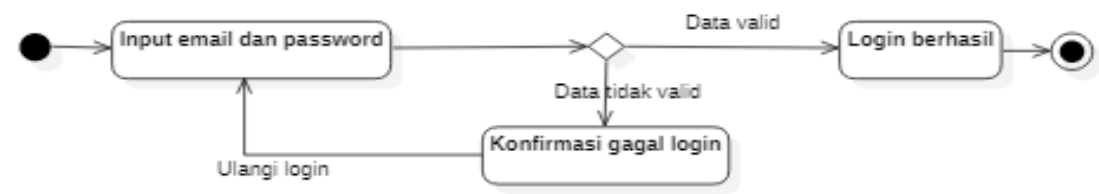

Gambar 8. Statechart Diagram Login

Gambar 8 menjelaskan mengenai proses login user. Dimana user memasukkan data berupa email dan password lalu sistem akan menvalidasi inputan, jika data valid maka berhasil login jika data tidak valid maka gagal login dan harus mengulang.

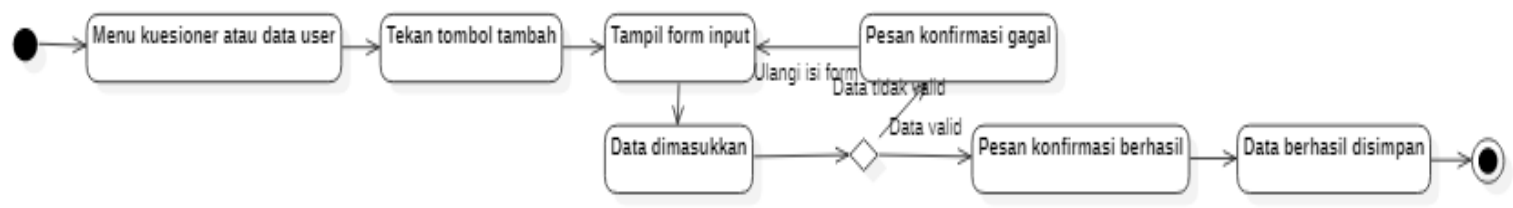

Gambar 9. Statechart Diagram Tambah Data

Gambar 9 menjelaskan mengenai proses tambah data. Pertama yang dilakukan adalah menekan tombol tambah maka akan muncul tampilan form tambah lalu masukkan data yang diperlukan, jika data valid akan mendapatkan pesan konfirmasi berhasil dan data berhasil disimpan jika data tidak valid maka harus mengulang isi form tambah. 
ISSN 2614-5278 (media cetak), ISSN 2548-8368 (media online)

Available Online at https://ejurnal.stmik-budidarma.ac.id/index.php/mib DOI 10.30865/mib.v5i3.3033

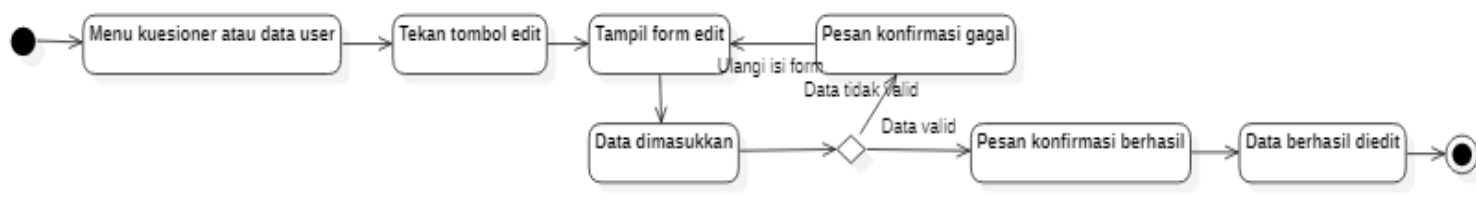

Gambar 10. Statechart Diagram Edit Data

Gambar 10 menjelaskan mengenai edit data. Pertama tekan tombol edit maka akan muncul tampilan form edit data lalu pilih data yang ingin di ubah dan masukkan data, jika data valid maka akan mendapatkan pesan konfirmasi berhasil dan data berhasil disimpan jika data tidak valid maka harus mengulang.

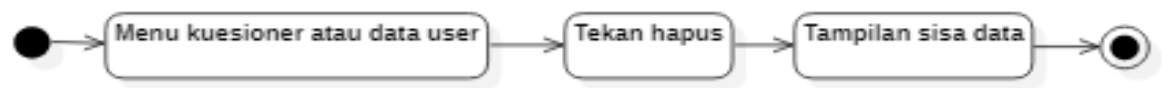

Gambar 11. Statechart Diagram Data Hapus Data

Gambar 11 menjelaskan mengenai hapus data. Yang dilakukan oleh user adalah dengan menekan hapus dan sistem akan mengarahkan pada tampilan sisa data.

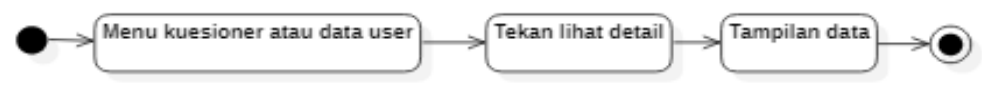

Gambar 12. Statechart Diagram Data View Data

Gambar 12 menjelaskan mengenai lihat detail data. Yang dilakukan oleh user adalah dengan menekan lihat detail dan sistem akan mengarahkan pada tampilan detail data yang sudah dipilih.

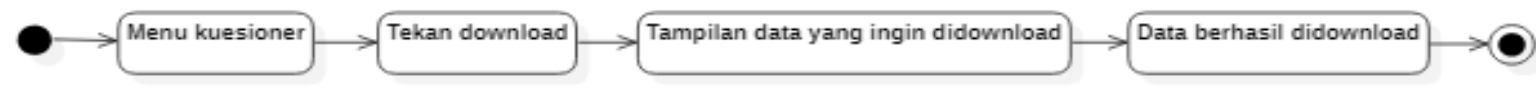

Gambar 13. Statechart Diagram Data Download Data

Gambar 13 menjelaskan mengenai download data. Yang dilakukan oleh user adalah dengan menekan download dan sistem akan mengarahkan pada tampilan data serta muncul simpan data.

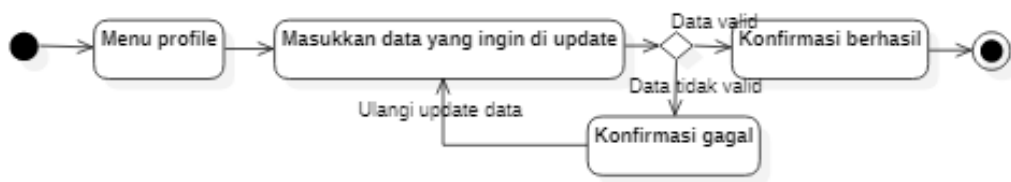

Gambar 14. Statechart Diagram Data Update Data Profil

Gambar 14 menjelaskan mengenai update data profil. User dapat memilih data apa saja yang ingin di update lalu memasukkan data, jika data valid maka muncul konfirmasi berhasil jika data tidak valid maka harus mengulang.

\subsection{Hasil Program}

Hasil pada riset ini adalah sistem Tracer Study berbasis web menggunakan framework Laravel. Penggunaan framework Laravel di sistem ini terdapat pada bagian user Alumni, Dosen, Pimpinan Fakultas dan Admin yaitu mulai dari halaman utama, halaman register, menu kuesioner, menu data user, menu edit profile dan semua tampilan tersebut menggunakan template yang sama. Hasil program dapat dilihat pada Gambar 15-Gambar 24.

a. Halaman Utama

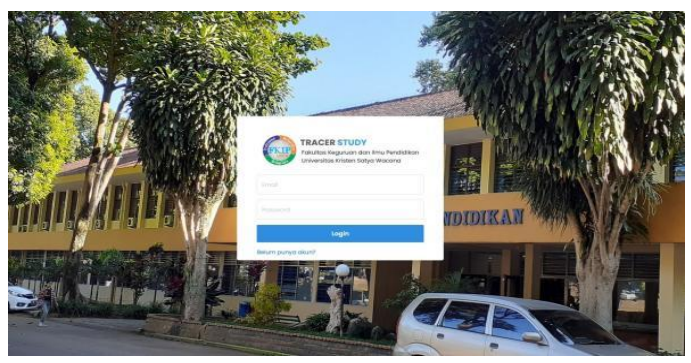

Gambar 15. Halaman Utama

Alfira Karisma Putri, Copyright (C2021, MIB, Page 1032 
Gambar 15 merupakan tampilan halaman utama. Ketika mengakses sistem ini maka akan diarahkan pada halaman login. Pada halaman ini akan diminta untuk memasukkan email dan kata sandi.

b. Halaman Daftar

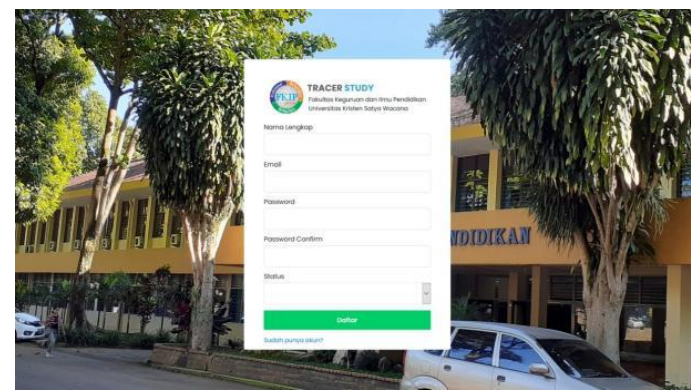

Gambar 16. Halaman Register

Gambar 16 merupakan tampilan halaman register. Ketika user belum memiliki akun pada sistem maka diwajibkan untuk melakukan register, dengan menginputkan nama lengkap, email, kata sandi dan status user.

c. Alumni

1. Tampilan Kuesioner

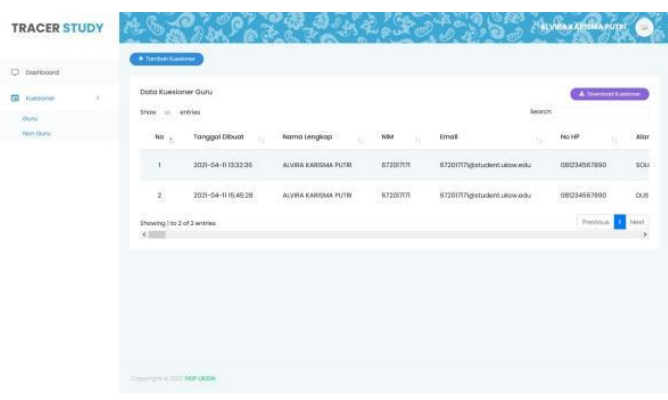

Gambar 17. Tampilan Kuesioner

Gambar 17 merupakan tampilan halaman kuesioner untuk user Alumni. User dapat melakukan tambah kuesioner, lihat detail kuesioner, edit kuesioner, hapus kuesioner dan download kuesioner.

2. Tampilan Tambah Kuesioner

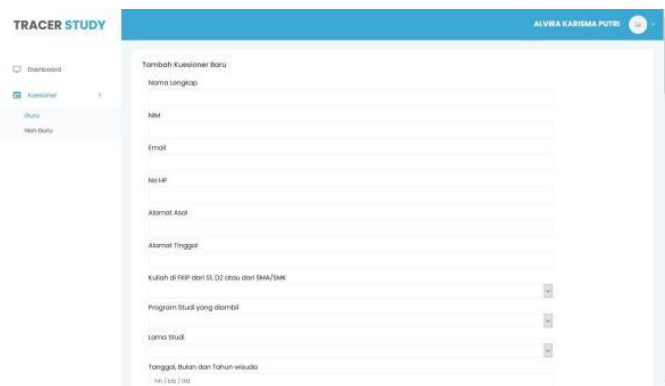

Gambar 18. Tampilan Tambah Kuesioner

Gambar 18 merupakan tampilan saat user ingin menambah data kuesioner guru atau non guru. Pada inputan akan otomatis menggunakan huruf kapital supaya data yang dihasilkan terlihat rapi dan sama. User akan menjawab pertanyaan yang sudah disediakan FKIP UKSW Salatiga.

3. Tampilan Edit Profil

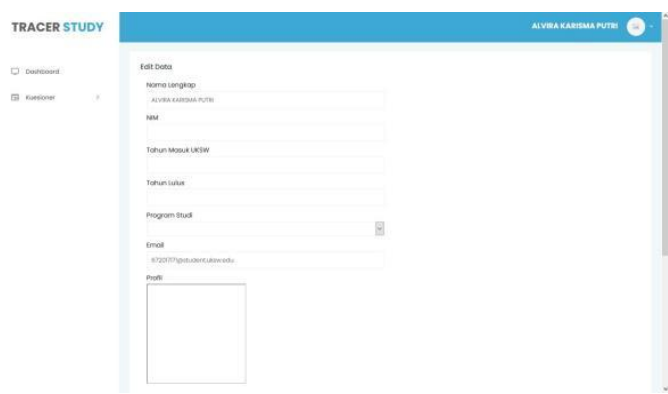

Gambar 19. Tampilan Edit Profile 
Gambar 19 merpakan tampilan saat user ingin mengubah atau menambahkan data user. Data yang dapat ditambahkan dan diubah adalah nama lengkap, NIM, tahun masuk FKIP UKSW Salatiga, tahun lulus, d. Dosen program studi, email, foto profil dan kata sandi.

1. Tampilan Kuesioner

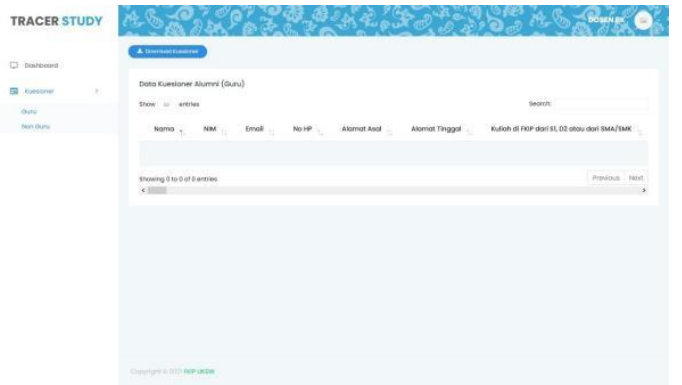

Gambar 20. Tampilan Kuesioner

Gambar 20 merupakan tampilan halaman kuesioner untuk user Dosen. User hanya dapat melihat detail kuesioner dan download kuesioner. Pada halaman ini dapat menampilkan data kuesioner sesuai dengan program studi yang diampu. Missal user adalah dosen Bimbingan Koseling maka data yang akan ditampilkan adalah data kuesioner dengan program studi Bimbingan Konseling saja.

2. Tampilan Edit Profile

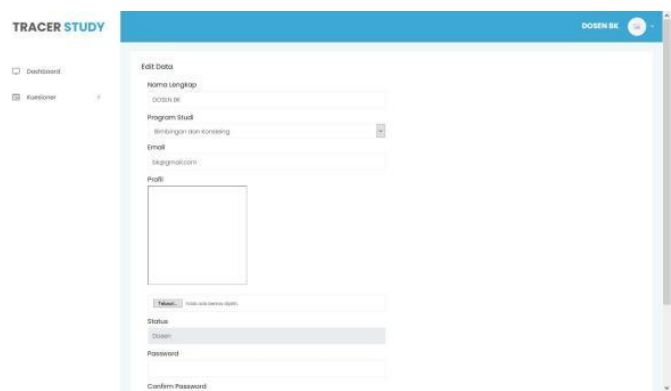

Gambar 21. Tampilan Edit Profile

Gambar 21 merupakan tampilan saat user ingin mengubah atau menambahkan data user. Data yang dapat ditambahkan adalah nama lengkap, program studi, email. Foto profil dan kata sandi.

e. Pimpinan Fakultas dan Admin

1. Tampilan Kuesioner

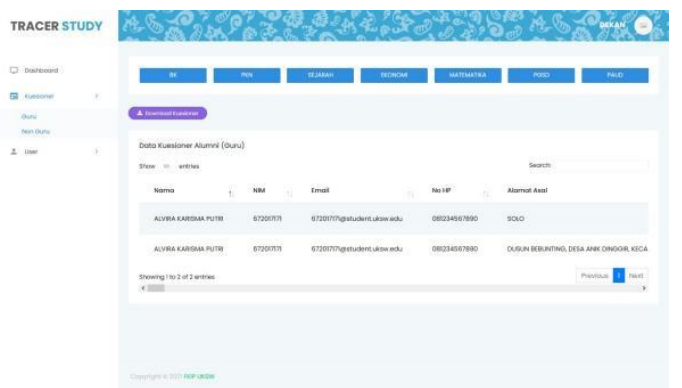

Gambar 22. Tampilan Kuesioner

Gambar 22 merupakan tampilan halaman kuesioner untuk user Pimpinan Fakultas dan Admin. User hanya dapat melihat detail kuesioner dan download kuesioner. Pada halaman ini dapat menampilkan data kuesioner dari semua program studi, bisa juga melihat kuesioner sesuai dengan program studi.

2. Tampilan Data User 
ISSN 2614-5278 (media cetak), ISSN 2548-8368 (media online)

Available Online at https://ejurnal.stmik-budidarma.ac.id/index.php/mib DOI 10.30865/mib.v5i3.3033

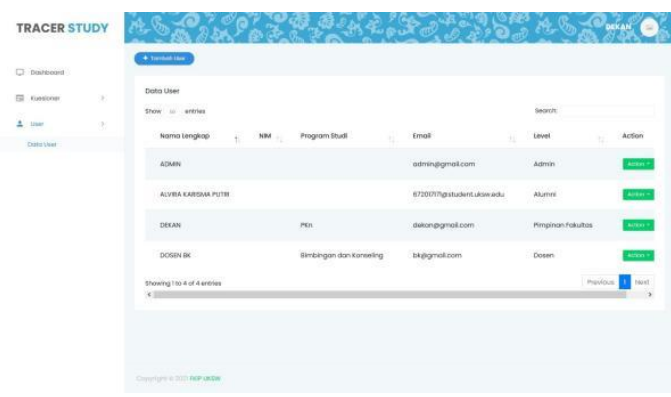

Gambar 23. Tampilan Data User

Gambar 23 merupakan tampilan data user yang hanya bisa diakses oleh Pimpinan Fakultas dan Admin. User dapat menambahkan data, edit, dan hapus data.

3. Tampilan Edit Profil

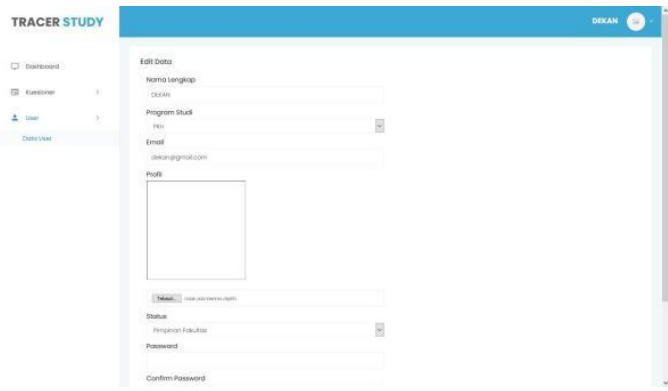

Gambar 24. Tampilan Data User

Gambar 24 merupakan tampilan saat user ingin mengubah atau menambahkan data user. Data yang dapat ditambahkan dan diubah adalah nama lengkap, program studi, email, foto profil dan kata sandi.

\subsection{Hasil Pengujian}

Setelah sistem berhasil dibuat, maka tahap selanjutnya adalah pengujian sistem. Pengujian sistem bertujuan untuk menemukan kesalahan pada sistem yang akan diuji, dengan menggunakan Blackbox Testing sistem dapat meminimalisir kesalahan dan untuk melihat fungsi dari sistem sudah berjalan sesuai yang diinginkan FKIP UKSW Salatiga yang sudah diidentifikasi [17]. Hasil Blackbox Testing dapat dilihat pada table 1.

Tabel 1. Hasil Blackbox Testing

\begin{tabular}{|c|c|c|c|c|}
\hline $\begin{array}{c}\text { Pola } \\
\text { Pengujian }\end{array}$ & Test Case & Hasil yang diharapkan & $\begin{array}{c}\text { Hasil } \\
\text { Pengujian } \\
\end{array}$ & Kesimpulan \\
\hline Register & $\begin{array}{c}\text { Mengisi } \\
\text { semua isian } \\
\text { dengan benar. }\end{array}$ & $\begin{array}{c}\text { Sistem akan menerima } \\
\text { akses register dan kemudian } \\
\text { diarahkan pada halaman } \\
\text { dashboard. }\end{array}$ & $\begin{array}{c}\text { Sesuai } \\
\text { harapan }\end{array}$ & Valid \\
\hline Register & $\begin{array}{l}\text { Mengosongkan } \\
\text { satu atau lebih } \\
\text { isian form } \\
\text { register. }\end{array}$ & $\begin{array}{c}\text { Sistem akan menolak } \\
\text { akses register dan memberikan } \\
\text { pesan } \text { error kemudian } \\
\text { akan kembali pada } \\
\text { halaman register. }\end{array}$ & $\begin{array}{c}\text { Sesuai } \\
\text { harapan }\end{array}$ & Valid \\
\hline Login & $\begin{array}{l}\text { Mengisi } \\
\text { semua isian } \\
\text { dengan benar. }\end{array}$ & $\begin{array}{l}\text { Sistem akan menerima } \\
\text { akses login dan kemudian diara } \\
\text { hkan pada } \\
\text { halaman dashboard. }\end{array}$ & $\begin{array}{l}\text { Sesuai } \\
\text { harapan }\end{array}$ & Valid \\
\hline Login & $\begin{array}{l}\text { Mengosongkan } \\
\text { isian email atau } \\
\text { password. }\end{array}$ & $\begin{array}{c}\text { Sistem akan memberikan } \\
\text { pesan error dan sistem akan } \\
\text { mengarahkan } \\
\text { pada halaman login. }\end{array}$ & $\begin{array}{l}\text { Sesuai } \\
\text { harapan }\end{array}$ & Valid \\
\hline
\end{tabular}


ISSN 2614-5278 (media cetak), ISSN 2548-8368 (media online)

Available Online at https://ejurnal.stmik-budidarma.ac.id/index.php/mib DOI 10.30865/mib.v5i3.3033

\begin{tabular}{|c|c|c|c|c|}
\hline $\begin{array}{c}\text { Pola } \\
\text { Pengujian }\end{array}$ & Test Case & Hasil yang diharapkan & $\begin{array}{c}\text { Hasil } \\
\text { Pengujian }\end{array}$ & Kesimpulan \\
\hline $\begin{array}{c}\text { Tambah } \\
\text { Kuesioner }\end{array}$ & $\begin{array}{c}\text { Mengisi } \\
\text { semua isian } \\
\text { form kuesioner } \\
\text { dengan benar. }\end{array}$ & $\begin{array}{l}\text { Sistem akan menerima } \\
\text { akses tambah kuesioner dan } \\
\text { kemudian diarahkan } \\
\text { pada halaman index } \\
\text { untuk user Alumni. }\end{array}$ & $\begin{array}{c}\text { Sesuai } \\
\text { harapan }\end{array}$ & Valid \\
\hline $\begin{array}{l}\text { Tambah } \\
\text { Kuesioner }\end{array}$ & $\begin{array}{c}\text { Mengosongkan } \\
\text { satu atau lebih } \\
\text { isian form } \\
\text { kuesioner. }\end{array}$ & $\begin{array}{c}\text { Sistem akan memberikan } \\
\text { pesan error sesuai dengan } \\
\text { isian apa yang } \\
\text { dikosongkan dan kemudian } \\
\text { sistem akan mengarahkan } \\
\text { kembali pada form kuesioner. }\end{array}$ & $\begin{array}{l}\text { Sesuai } \\
\text { harapan }\end{array}$ & Valid \\
\hline $\begin{array}{c}\text { Hapus } \\
\text { Kuesioner }\end{array}$ & $\begin{array}{l}\text { Klik tombol } \\
\text { hapus. }\end{array}$ & $\begin{array}{c}\text { File akan terhapus sesuai } \\
\text { dengan ID. }\end{array}$ & $\begin{array}{l}\text { Sesuai } \\
\text { harapan }\end{array}$ & Valid \\
\hline $\begin{array}{c}\text { Edit } \\
\text { Kuesioner }\end{array}$ & $\begin{array}{l}\text { Mengisi form } \\
\text { pada data yang } \\
\text { ingin diubah. }\end{array}$ & $\begin{array}{c}\text { Sistem akan memberikan } \\
\text { notifikasi bahwa data berhasil } \\
\text { diubah. }\end{array}$ & $\begin{array}{l}\text { Sesuai } \\
\text { harapan }\end{array}$ & Valid \\
\hline $\begin{array}{c}\text { Tambah } \\
\text { Data User }\end{array}$ & $\begin{array}{l}\text { Mengisian } \\
\text { semua isian } \\
\text { form data } \\
\text { user dengan } \\
\text { benar. }\end{array}$ & $\begin{array}{c}\text { Sistem akan menerima } \\
\text { akses tambah data } \text { user dan } \\
\text { kemudian diarahkan } \\
\text { pada halaman form tambah } \\
\text { data. }\end{array}$ & $\begin{array}{c}\text { Sesuai } \\
\text { harapan }\end{array}$ & Valid \\
\hline $\begin{array}{c}\text { Tambah } \\
\text { Data User }\end{array}$ & $\begin{array}{c}\text { Mengosongkan } \\
\text { satu atau lebih } \\
\text { isian form } \\
\text { data } \text { user. }\end{array}$ & $\begin{array}{c}\text { Sistem akan memberikan } \\
\text { pesan } \text { error sesuai dengan } \\
\text { isian apa yang } \\
\text { dikosongkan dan kemudian } \\
\text { sistem akan mengarahkan } \\
\text { kembali pada form data } \text { user. }\end{array}$ & $\begin{array}{c}\text { Sesuai } \\
\text { harapan }\end{array}$ & Valid \\
\hline $\begin{array}{l}\text { Hapus Data } \\
\text { User }\end{array}$ & $\begin{array}{l}\text { Klik tombol } \\
\text { hapus. }\end{array}$ & $\begin{array}{c}\text { File akan terhapus sesuai } \\
\text { dengan ID. }\end{array}$ & $\begin{array}{l}\text { Sesuai } \\
\text { harapan }\end{array}$ & Valid \\
\hline $\begin{array}{l}\text { Edit Data } \\
\quad \text { User }\end{array}$ & $\begin{array}{l}\text { Mengisi form } \\
\text { pada data yang } \\
\text { ingin diubah. }\end{array}$ & $\begin{array}{c}\text { Sistem akan memberikan } \\
\text { notifikasi bahwa data berhasil } \\
\text { diubah. }\end{array}$ & $\begin{array}{l}\text { Sesuai } \\
\text { harapan }\end{array}$ & Valid \\
\hline Download & $\begin{array}{l}\text { Klik tombol } \\
\text { download. }\end{array}$ & $\begin{array}{l}\text { Sistem akan memberikan } \\
\text { tampilan save file. }\end{array}$ & $\begin{array}{c}\text { Sesuai } \\
\text { harapan }\end{array}$ & Valid \\
\hline
\end{tabular}

Berdasarkan tabel 1 dapat dijelaskan bahwa hasil pengujian pada sistem Tracer Study ini tidak terjadi kesalahan. Hasil pengujian ini dapat memperlihatkan bahwa perancangan sistem Tracer Study sesuai dengan harapan yang diinginkan FKIP UKSW Salatiga.

\section{KESIMPULAN}

Sistem Tracer Study berhasil dibuat menggunakan framework Laravel dengan menggunakan proses pengembangan User Centered Design. Dengan tahapan penelitian yang pertama adalah mengidentifikasikan masalah sistem Tracer Study yang akan dibuat seperti apa dan bagaimana, kemudian mengumpulkan data seperti data Alumni, data dosen, data pimpinan fakultas, data pertanyaan yang akan diajukan pada form kuesioner dan data yang lainnya, kemudian merancang sistem Tracer Study seperti merancang desain tampilan website dan merancang fungsi apa saja yang dibutuhkan dalam sistem informasi Tracer Study ini, kemudian mengimplementasikan sistem Tracer Study, kemudian menguji sistem informasi Tracer Study dengan memakai blackbox testing dan menulis laporan dalam bentuk laporan dan artikel. Sistem ini dapat digunakan memperoleh data Alumni FKIP UKSW Salatiga. Sistem ini dapat membantu mempermudah FKIP UKSW Salatiga dalam 
pendataan Alumni untuk kebutuhan yang diperlukan seperti akreditasi ataupun kebutuhan yang lainnya dan mempermudah Alumni dalam pengisian kuesioner Tracer Study. Dan dapat mempermudah Alumni FKIP UKSW Salatiga dalam pengisian kuesioner. Sistem informasi Tracer Study ini akan menyimpan data yang dibutuhkan oleh FKIP UKSW Salatiga mengenai Alumni FKIP UKSW Salatiga. Dan sistem informasi Tracer Study ini berhasil berjalan dengan baik seperti fungsi tambah kuesioner, edit kuesioner, hapus kuesioner, lihat kuesioner, download kuesioner, tambah data user, edit data user, hapus data user.

\section{REFERENCES}

[1] A. F. Pakpahan, "Dasar-Dasar Pengembangan Aplikasi Web Modern dengan Framework Laravel - Google Books."'https://www.google.co.id/books/edition/Dasar_Dasar_Pengembangan_Aplikasi_Web_Mo/KfIIEAAAQBAJ?hl $=\mathrm{id} \& \mathrm{gbpv}=1 \& \mathrm{dq}=$ perkembangan+teknologi+framework\&pg=PR5\&printsec=frontcover $($ accessed April 26, 2021).

[2] E. Noviyantono and Aidil, "Integration System Of Web Based And SMS Gateway For Information System Of Tracer Study," 1st International Conference on Engineering and Technology Development (ICETED) 2012, 2012.

[3] Universitas Hasanuddin, "Tracer Study Universitas Hasanuddin - Google Books." https://www.google.co.id/books/edition/Tracer_Study_Universitas_Hasanuddin/utTnDwAAQBAJ?hl=id\&gbpv=1 (accessed April 26, 2021).

[4] M. Rizka, “Analisis Dan Perancangan Sistem Informasi Tracer Study Berbasis WEB.” J. Informatika, vol. 3, no. 2, pp.6973,2018

[5] T. Noor, S. Muhamad, and R. Indera, "Perancangan Aplikasi Tracer Study Alumni Jurusan Administrasi Bisnis Politeknik Negeri Banjarmasin Berbasis Web," J. Positif, vol. 2, no. 1, pp. 34-40, 2016.

[6] A. Febriani, W. Linda Wati, and H. Fonda, "Sistem Informasi Alumni Smp N 1 Dayun Menggunakan Framework Laravel Di Kab. Siak,” J. Ilmu Komputer, vol. 9, no. 2, pp. 65-70, Oct. 2020, doi: 10.33060/jik/2020/vo19.iss2.165.

[7] S. Al Ayubi, Y. T. Mursityo, and N. Y. Setiawan, "Pengembangan Sistem Informasi Tracer Study Fakultas Ilmu Komputer Universitas Brawijaya Menggunakan Metode Rational Unified Procces," J. Pengembangan Teknologi Informasi dan Ilmu Komputer, vol. 3, no. 5, pp. 4447-4454, 2019.

[8] F. Luthfi, "Penggunaan Framework Laravel Dalam Rancang Bangun Modul Back-End Artikel Website Bisnisbisnis.ID," JISKA (Jurnal Informatika Sunan Kalijaga), vol. 2, no. 1, pp. 34, Aug. 2017, doi: 10.14421/jiska.2017.21-05.

[9] L. Fitriani, D. Kurniadi, and Z. R. Fikri, "Pengembangan Sistem Informasi Tracer Study di Sekolah Tinggi Teknologi Garut," J. Algoritma, vol. 16, no. 2, pp. 263-269, 2019.

[10] Y. Yudhanto, "Panduan Pintar Belajar phpMyAdmin Dasar - Google Books." https://www.google.co.id/books/edition/Panduan_Pintar_Belajar_phpMyAdmin_Dasar/44V7DwAAQBAJ?hl=id\&gbp $\mathrm{v}=1 \& \mathrm{dq}=$ phpmyadmin + adalah\&printsec=frontcover $($ accessed April 27, 2021).

[11] Y. A. Adi Soetrisno, “Aplikasi Tracer Study Berbasis Web Pada Universitas Diponegoro,” Transmisi, vol. 21, no. 4, pp. 135-146, Nov. 2019, doi: 10.14710/transmisi.21.4.135-146.

[12] I. Saputri, M. Fadhli, and I. Surya, "Penerapan Metode UCD (User Centered Design) Pada E-Commerce Putri Intan Shop Berbasis Web," Jurnal Nasional Teknologi dan Sistem Informasi, vol. 3, no. 2, pp. 269-278, 2017.

[13] T. Vani, R. Hidayat, A. Yansen, and F. Danar, "Rancang Bangun Mobile Commerce di Lamandau Store Berbasis Android berdasarkan User Centered Design (UCD)," J. Media Informatika Budidarma, vol. 5, no. 1, pp. 287-296, 2021, doi: 10.30865/mib.v5i1.2544.

[14] E. Diana, "View of Analisis Dan Perancangan Sistem Informasi Tracer Study Berbasis Web." J. Media Sisfo, vol. 11, no. 2, pp. 817-829, 2017.

[15] Q. Mardzotillah and M. Ridwan, "Sistem Tracer Study Dan Persebaran Alumni Berbasis Web Di Univesitas Islam SyekhYusuf Tangerang," JUTIS, vol. 8, no. 1, pp. 90-106, 2020.

[16] G. Karyono and N. Hermanto, "Rancang Bangun Sistem Tracer Study Online pada STMIK AMIKOM Purwokerto," Semantik, vol. 3, no. 1, pp. 126-133, 2013.

[17] A. Rouf, "Pengujian Perangkat Lunak Dengan Menggunakan Metode White Box dan Back Box," J. Himsya Tech, vol. vol 8 no1, pp. 1-7, 2012. 